Canadian Journal of Fisheries and Aquatic Sciences, 1993, v.50, n.9, pp.1961-1968.

Online ISSN: $1205-7533$

Print ISSN: 0706-652X

DOI: $10.1139 / \mathrm{f} 93-218$

http://pubs.nrc-cnrc.gc.ca/rp-ps/journalDetail.jsp?jcode=cjfas\&lang=eng

http://article.pubs.nrc-

cnrc.gc.ca/RPAS/rpv?hm=HInit\&journal=cjfas\&volume=50\&calyLang=eng\&afpf=f93-218.pdf (C) 1993 NRC Canada 


\title{
Comparative Population Characteristics of Muskellunge (Esox masquinongy), Northern Pike (E. lucius), and Their Hybrid (E. masquinongy $\times$ E. lucius)
}

\author{
David H. Wahl' and Roy A. Stein \\ Department of Zoology and Ohio Cooperative Fish and Wildlife Research Unit, ${ }^{2}$ The Ohio State University, 1735 Neil Avenue,
} Columbus, OH 43210, USA

\begin{abstract}
Wahl, D.H., and R.A. Stein. 1993. Comparative population characteristics of muskellunge (Esox masquinongy), northern pike (E. lucius), and their hybrid (E. masquinongy $\times$ E. lucius). Can. J. Fish. Aquat. Sci. 50 : 1961-1968.
\end{abstract}

We compared growth, survival, diet, and angler catch of muskellunge (Esox masquinongy), northern pike (E. lucius), and tiger muskellunge ( $E$. masquinongy $\times E$. lucius) through $5 \mathrm{yr}$ after their introduction into three Ohio reservoirs. Muskellunge grew slower than northern pike and tiger muskellunge through the first year but faster than northern pike in subsequent years. Large stocked esocids $(180-205 \mathrm{~mm})$ survived better than small ones (145 mm). Survival patterns established through the first fall were maintained through age 5 ; northern pike survived best, followed by muskellunge and tiger muskellunge. Angler catch reflected differences in survival as well as catchability among taxa. Northern pike were caught at smaller sizes and younger ages than other taxa. Gizzard shad (Dorosoma cepedianum) dominated esocid diets for all taxa and age classes, followed by centrarchids and cyprinids. Prey length consumed increased linearly with esocid length; northern pike selected larger gizzard shad than either muskellunge or tiger muskellunge. These differences in population characteristics among esocids should influence mangement and stocking programs. Whereas northern pike maximize angling opportunities, muskellunge probably will provide trophy fisheries. Although tiger muskellunge can be reared inexpensively, they appear to provide little recreational fishing in return.

\begin{abstract}
Nous avons comparé la croissance, la survie, le régime alimentaire et les prises sportives de maskinongé (Esox masquinongy), de grand brochet ( $E$. lucius) et de maskinongé tigré ( $E$. masquinongy $\times E$. lucius) pendant les 5 a qui ont suivi leur introduction dans trois réservoirs de l'Ohio. Le maskinongé se développait plus lentement que le grand brochet et le maskinongé tigré pendant la première année, mais plus vite que le grand brochet des années suivantes. Les ésocidés de grande taille $(180-205 \mathrm{~mm}$ ) ont survécu mieux que les petits (145 mm). Les schémas de survie établis le premier automne se sont maintenus jusqu'à l'âge de 5 ans; le taux de survie était le meilleur pour le grand brochet, puis le maskinongé et enfin le maskinongé tigré. Les prises sportives reflétaient des différences entre les taxons en ce qui concerne la survie et la capturabilité. Le grand brochet était capturé à une taille plus petite et à un âge plus jeune que les autres taxons. L'alose à gésier (Dorosoma cepedianum) dominait dans le régime alimentaire des ésocidés pour tous les taxons et toutes les classes d'âge, suivie par les centrarchidés et les cyprinidés. La longueur des proies consommées augmentait de façon linéaire en fonction de la longueur des ésocidés; le grand brochet choisissait des aloses à gésier de plus grande taille que ne le faisaient le maskinongé ou le maskinongé tigré. Ces différences parmi les ésocidés dans les caractéristiques démographiques devraient avoir un effet dans les programmes de gestion et de repeuplement. Tandis que le grand brochet maximise les possibilités de pêche sportive, le maskinongé va probablement offrir des pêches de trophée. Bien que le maskinongé tigré puisse être élevé de façon peu coûteuse, cette espèce semble offrir peu de résultats sur le plan de la pêche sportive.
\end{abstract}

Received luly 17, 1992

Accepted April 14, 1993

(JB561)
Reçu le 17 juillet 1992 Accepté le 14 avril 1993 uskellunge (Esox masquinongy), northern pike (E. lucius), and their hybrid, tiger muskellunge (E. masquinongy $\times$ E. lucius), are the largest and most abundant esocid sport fish in North America (Crossman

'Present address: Center for Aquatic Ecology, Illinois Natural History Survey and Department of Ecology, Ethology, and Evolution, University of Illinois, 607 E. Peabody Drive, Champaign, IL 61820 , USA.

${ }^{2}$ The unit is sponsored jointly by the U.S. Fish and Wildlife Service, the Ohio Department of Natural Resources, The Ohio State University, and the Wildlife Management Institute.
1978). Tiger muskellunge typically occur naturally only in low numbers (Crossman and Buss 1965), but they have been widely introduced (Wingate 1986). Whereas investigators have examined population attributes of these taxa individually, quantifying growth (Bimber 1982; Diana 1983b; Kipling 1983; Newman and Storck 1986), survival (Casselman 1978; Bimber 1982) and diet (Frost 1954; Lawler 1965; Mann 1976; Wolfert 1978), few studies have compared these taxa directly, as they rarely cooccur. Recent research has addressed some comparative aspects of juvenile esocids (Wahl and Stein 1988, 1991); however, comparative data for older fish, which are critical to the development of effective management programs, are sparse. 
TABLE 1. Location, date, number, and size of tiger muskellunge (TM), muskellunge (M), and northern pike (NP) stocked into three Ohio reservoirs. Length (nearest $1.0 \mathrm{~mm}$ ) and weight (nearest $0.1 \mathrm{~g}$ ) for each taxon were based on a sample $(N=100)$ measured the day before stocking (from Wahl and Stein 1989).

\begin{tabular}{|c|c|c|c|c|c|c|c|c|}
\hline \multirow{2}{*}{$\begin{array}{l}\text { Reservoir } \\
\text { (ha) }\end{array}$} & \multirow{2}{*}{$\begin{array}{l}\text { Stocking } \\
\text { date }\end{array}$} & \multirow{2}{*}{$\begin{array}{c}\text { No. of } \\
\text { each taxon }\end{array}$} & \multicolumn{3}{|c|}{ Total length $\pm 95 \% \mathrm{CI}$} & \multicolumn{3}{|c|}{ Wet weight $\pm 95 \% \mathrm{CI}$} \\
\hline & & & TM & M & NP & TM & M & NP \\
\hline North $(89)$ & 29 Aug. 1983 & 1150 & $183 \pm 3.0$ & $180 \pm 3.9$ & - & $29.0 \pm 1.6$ & $24.6 \pm 1.9$ & - \\
\hline Kokosing (46) & 9 Aug. 1984 & 1150 & $145 \pm 2.4$ & $147 \pm 4.5$ & $145 \pm 2.5$ & $12.8 \pm 0.7$ & $11.4 \pm 1.3$ & $11.2 \pm 0.8$ \\
\hline North & 4 Sept. 1984 & 3000 & $177 \pm 2.2$ & $179 \pm 4.2$ & $179 \pm 3.5$ & $24.4 \pm 1.1$ & $23.9 \pm 1.9$ & $30.7 \pm 1.9$ \\
\hline Madison (40) & 29 July 1985 & 1000 & $147 \pm 2.8$ & $144 \pm 3.0$ & $143 \pm 1.7$ & $13.9 \pm 1.0$ & $11.8 \pm 1.0$ & $14.7 \pm 0.8$ \\
\hline North & 26 Aug. 1985 & 2150 & $208 \pm 4.5$ & $205 \pm 3.9$ & $205 \pm 4.7$ & $44.3 \pm 2.7$ & $39.4 \pm 2.6$ & $44.6 \pm 3.6$ \\
\hline
\end{tabular}

Habitat degradation and overexploitation have forced managers to stock esocids to maintain populations (Wingate 1986). Once potential impacts on natural populations have been considered (Inskip and Magnuson 1986; Koppelman and Philipp 1986), the decision as to which taxon to stock depends on trade-offs between hatchery adaptability and poststocking performance. Tiger muskellunge have hatchery advantages over their parents, for they grow faster, accept dry-pellet diets more readily, and resist disease (Hesser 1978). Few data are available to compare poststocking performance of these esocids in terms of growth, survival, and harvest. Below, we review our expectations regarding these parameters.

Growth varies with taxon, food consumption, and temperature. Although geographic distributions of the two parent species overlap, muskellunge are distributed farther south than northern pike (Crossman 1978). As such, optimal temperatures for growth may differ. With a bioenergetic model, Bevelhimer et al. (1985) predicted that tiger muskellunge should outgrow northern pike and muskellunge under most thermal regimes. In the field, juvenile tiger muskellunge grow faster than northern pike in ponds (Weithman and Anderson 1977) but at similar rates in reservoirs (Wahl and Stein 1991); muskellunge grow most slowly. To judge long-term growth consequences, comparative data for adult esocids are required. Only by comparing across taxa within one system can growth differences be ascribed to taxon effects rather than temperature, prey composition, or prey abundance.

Survival may vary with taxon, size, and system-specific characteristics. Mechanisms underlying survival in juvenile stocked escoids are now broadly understood. Stress at stocking (Mather and Wahl 1989), resident predators (Stein et al. 1981; Wahl and Stein 1989), and forage base (Carline et al. 1986; Wahl and Stein 1988) have been assessed; these data provide insight into the ecology of these fishes, allowing development of taxonspecific management programs. In spite of these advances, however, additional progress has been limited by the lack of quantitative assessments of comparative mortality for both juvenile and adult esocids. Similarly, without comparative harvest data, which depend on survival and relative catchability, management decisions are compromised.

Prey choice may differ with taxa and ultimately affect esocid growth and survival as well as determine impacts on other trophic levels. As top camivores, esocids may well influence community structure. In fact, esocids have been historically used to control undesirable species and improve angling (Wingate 1986). Success of this approach depends on prey preference. Juvenile esocids select prey based on size, density, and species of prey (Mauck and Coble 1971; Weithman and Anderson 1977; Gillen et al. 1981; Tomcko et al. 1984; Carline et al. 1986; Wahl and Stein 1988). Without comparative prey selectivity data for larger esocids, our ability to predict how these predators will influence prey populations is substantially constrained.

In this study, we compare growth, survival, prey preference, and angler catch of muskellunge, northern pike, and their hybrid. In particular, we evaluate whether relationships among taxa previously established for juvenile fish (Wahl and Stein 1988, 1991 ) occur in older esocids. In addition, by matching esocid life history traits and performance to system-specific characteristics, we can increase our ability to establish viable populations. Because esocid taxa probably differ in their growth, survival, prey selectivity, and catchability, our work provides insight into which taxon should be stocked, at what size, where, and for what management purpose.

\section{Methods}

We quantified growth, survival, diet, and angler harvest of tiger muskellunge, muskellunge, and northern pike for $5 \mathrm{yr}$ after their introduction into three shallow, relatively small $(<90$ ha) Ohio reservoirs (Table 1). All three reservoirs are within the natural range of muskellunge and northern pike (Scott and Crossman 1973). Esocids for each introduction were obtained from Ohio Division of Wildlife fish hatcheries. The northern pike stock used in these crosses originated from Lake Erie and has been maintained at the St. Marys hatchery since initial collection over $25 \mathrm{yr}$ ago (Bevelhimer et al. 1985). Muskellunge parents were obtained from Ohio reservoirs and are from a recognized subspecies, $E$. $m$. ohioensis, originating from the Ohio River drainage system (Scott and Crossman 1973; Bevelhimer et al. 1985; Koppelman and Philipp 1986). Each reservoir stocking $N=5$ total) received equal numbers and similar sizes $(145,180$, or $205 \mathrm{~mm}$ ) of each esocid taxon (see Wahl and Stein 1991 for rearing details). Esocids were counted and 100 were measured (total length, nearest $1 \mathrm{~mm}$ ) and weighed (nearest $0.1 \mathrm{~g}$ ) the day before stocking (Table 1).

Esocids were collected by electroshocking (300 V, pulsed DC) the entire perimeter of each reservoir twice and trapnetting (13-mm bar mesh, $N=12$ net-days) every 2 wk during each fall (September through November) and spring (March through May) following stocking. Trapnetting was used to sample those esocids 2 yr of age and older. Esocids captured were measured (total length, nearest $1 \mathrm{~mm}$ ) and weighed (nearest $1.0 \mathrm{~g}$ ). Stomach contents were recovered by pulsed gastric lavage (Foster 1977), frozen, and then thawed for analysis. Recovered prey 
TABLE 2. Survival through first fall for tiger muskellunge (TM), muskellunge (M), and northern pike (NP) after each of three (two for northern pike) stockings in North Reservoir, Ohio. Population estimates are based on Schnabel mark-recapture during October through November. See Table 1 for initial conditions at stocking.

\begin{tabular}{|c|c|c|c|c|}
\hline Year & $\begin{array}{l}\text { Length } \\
\text { group }\end{array}$ & Taxa & $\begin{array}{c}\text { Population } \\
\text { estimate } \\
(95 \% \mathrm{CI})\end{array}$ & $\begin{array}{c}\% \\
\text { survival } \\
(95 \% \mathrm{Cl})\end{array}$ \\
\hline \multirow[t]{2}{*}{1983} & 180 & TM & $125(76-361)$ & $11(7-31)$ \\
\hline & & $\mathrm{M}$ & $104(65-253)$ & $9(6-22)$ \\
\hline \multirow[t]{3}{*}{1984} & 180 & TM & $61(32-498)$ & $2(1-17)$ \\
\hline & & M & $104(86-131)$ & $3(3-4)$ \\
\hline & & $\mathrm{NP}$ & $1283(684-1406)$ & $43(23-47)$ \\
\hline \multirow[t]{3}{*}{1985} & 205 & $\mathrm{TM}$ & $82(53-180)$ & $4(2-8)$ \\
\hline & & $\mathrm{M}$ & $75(56-113)$ & $3(2-5)$ \\
\hline & & NP & $316(240-463)$ & $15(11-22)$ \\
\hline
\end{tabular}

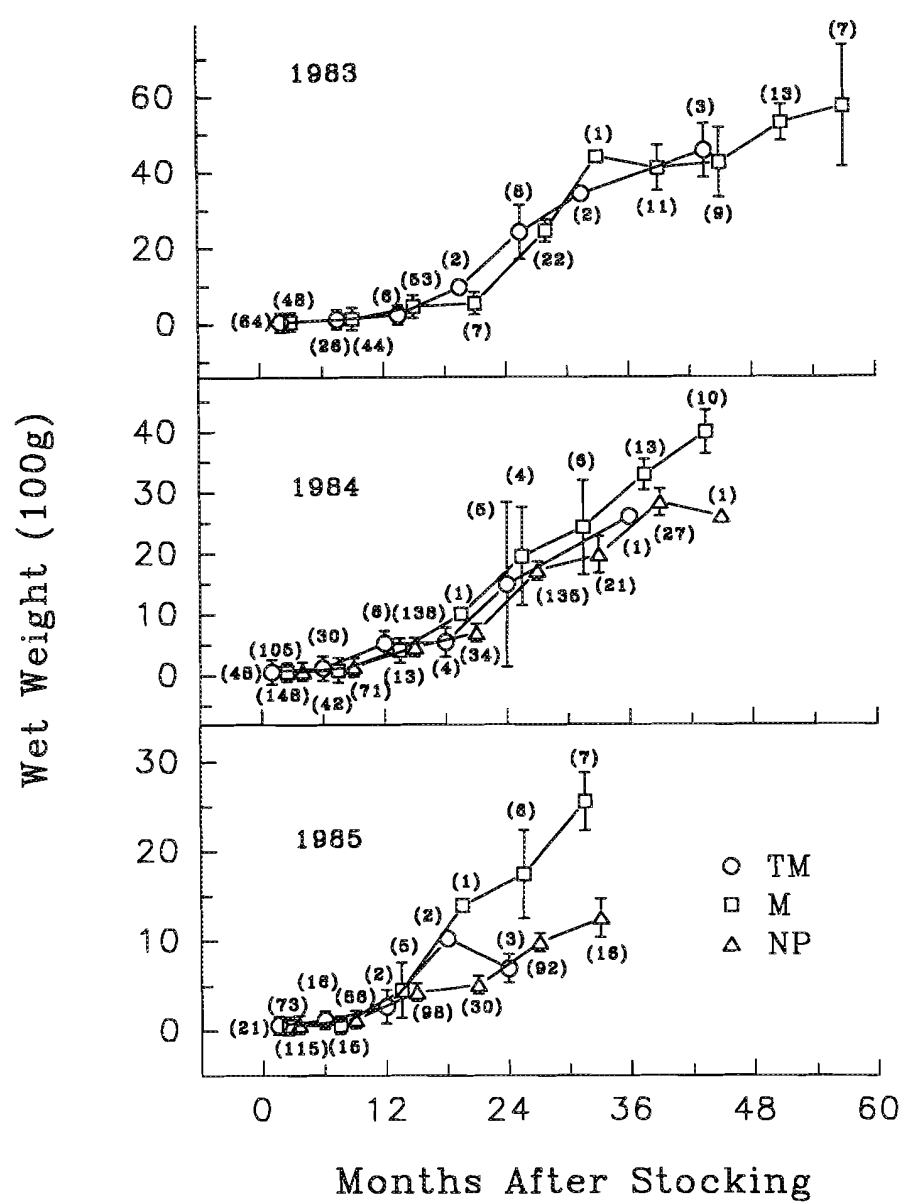

FIG. 1. Mean total weight for tiger muskellunge (TM), muskellunge (M), and northern pike (NP) following introduction into North Reservoir, Ohio, 1983-85. Sample sizes are in parentheses. Vertical lines are 95\% confidence intervals for samples $\geq 3$.

were identified to species; partially digested fish were identified using structures resistant to digestion. Fish that could not be identified $(<3 \%)$ were discarded. Prey were measured in length as total, standard, or backbone (nearest $1 \mathrm{~mm}$ ), depending on state of digestion, and weighed (nearest $0.01 \mathrm{~g}$ ). Prey total length was then back-calculated, if necessary, with regression equations (see Table 2 of Wahl and Stein 1991).
TABLE 3. Number of esocids caught by anglers as reported in a roving and volunteer creel in North Reservoir, Ohio, 1985-90. Values represent the number of tiger muskellunge (TM), muskellunge (M), and northern pike (NP) caught following three reservoir stockings, 1983-85. Northern pike were not stocked in 1983.

\begin{tabular}{lcrc}
\hline \hline Age $(\mathrm{yr})$ & TM & M & NP \\
\hline 2 & 0 & 3 & 32 \\
3 & 9 & 13 & 28 \\
$\geq 4$ & 3 & 14 & 4 \\
Total & 12 & 30 & 64 \\
\hline
\end{tabular}

Esocid survival was estimated from Schnabel mark-recapture population estimates (Ricker 1975). Esocids were fin-clipped for these population estimates, which represent the midpoint of each fall and spring sample. During the first fall, mark-recapture sampling was done during mid-October through mid-December.

Relative angler catch rates of the three esocids were determined from a roving and volunteer creel survey in North Reservoir. Creel clerks interviewed anglers randomly during periods of high fishing effort. Signs also were posted near the lake requesting anglers to record information from fish returned to the lake and to bring harvested esocids to Ohio Division of Wildlife offices. There were no size limits or other regulations in effect on North Reservoir during our study. All fish obtained from the roving and volunteer creels were identified, measured, and weighed.

\section{Results}

\section{Growth Rates}

Neither lengths (ANOVA, $P=0.49)$ nor weights $(P=0.72)$ of esocids captured by electrofishing and trapnetting differed across taxa, years, and sample periods. Thus, we combined growth data for esocids collected by these two gears. Lengths increased linearly through age 5 and were similar for most comparisons in three years in North Reservoir (ANCOVA, homogeneity of slope, $P>0.16$ ); only muskellunge stocked in 1985 grew faster than northern pike after age 2 (ANCOVA, $P=0.015$ ). Sex-specific growth rates were not calculated; sex ratios were about 1:1 for all taxa and stockings. Weight gain followed two linear growth stanzas, one for age- 0 esocids and a second for age-1 through age-5 fish (Fig. 1). Linear models provided better 
TABLE 4. Percentage of total prey weight of various prey species recovered from age-0 through age- 3 tiger muskellunge (TM), muskellunge (M), and northern pike (NP) stomachs in North Reservoir, Ohio, 1983-88. Invertebrates contributed in only two instances: $2 \%$ for age-1 tiger muskellunge and northern pike. Numbers of each esocid sampled are given in parentheses.

\begin{tabular}{|c|c|c|c|c|c|c|c|c|c|c|c|c|}
\hline \multirow[b]{2}{*}{ Prey } & \multicolumn{3}{|c|}{ Age 0} & \multicolumn{3}{|c|}{ Age 1} & \multicolumn{3}{|c|}{ Age 2} & \multicolumn{3}{|c|}{ Age 3} \\
\hline & $\begin{array}{c}\text { TM } \\
(881)\end{array}$ & $\begin{array}{c}\text { M } \\
(1171)\end{array}$ & $\begin{array}{c}N P \\
(938)\end{array}$ & $\begin{array}{l}\text { TM } \\
(90)\end{array}$ & $\begin{array}{c}M \\
(176)\end{array}$ & $\begin{array}{c}\text { NP } \\
(421)\end{array}$ & $\begin{array}{l}\text { TM } \\
(24)\end{array}$ & $\begin{array}{c}M \\
(42)\end{array}$ & $\begin{array}{c}\text { NP } \\
(295)\end{array}$ & $\begin{array}{l}\mathrm{TM} \\
\text { (3) }\end{array}$ & $\begin{array}{c}\mathrm{M} \\
(43)\end{array}$ & $\begin{array}{l}\mathrm{NP} \\
(64)\end{array}$ \\
\hline Gizzard shad & 86 & 89 & 78 & 36 & 80 & 52 & 93 & 99 & 85 & 100 & 97 & 58 \\
\hline Lepomis spp. & 5 & 5 & 11 & 13 & 5 & 13 & 3 & 0 & 11 & 0 & 3 & 5 \\
\hline Cyprinidae & 0 & 1 & 1 & 3 & 2 & 5 & 0 & 0 & 2 & 0 & 0 & 0 \\
\hline Other fish & 8 & 5 & 10 & 47 & 2 & 28 & 3 & 1 & 2 & 0 & 0 & 37 \\
\hline \% empty & 55 & 58 & 43 & 68 & 58 & 51 & 50 & 43 & 45 & 0 & 60 & 52 \\
\hline
\end{tabular}

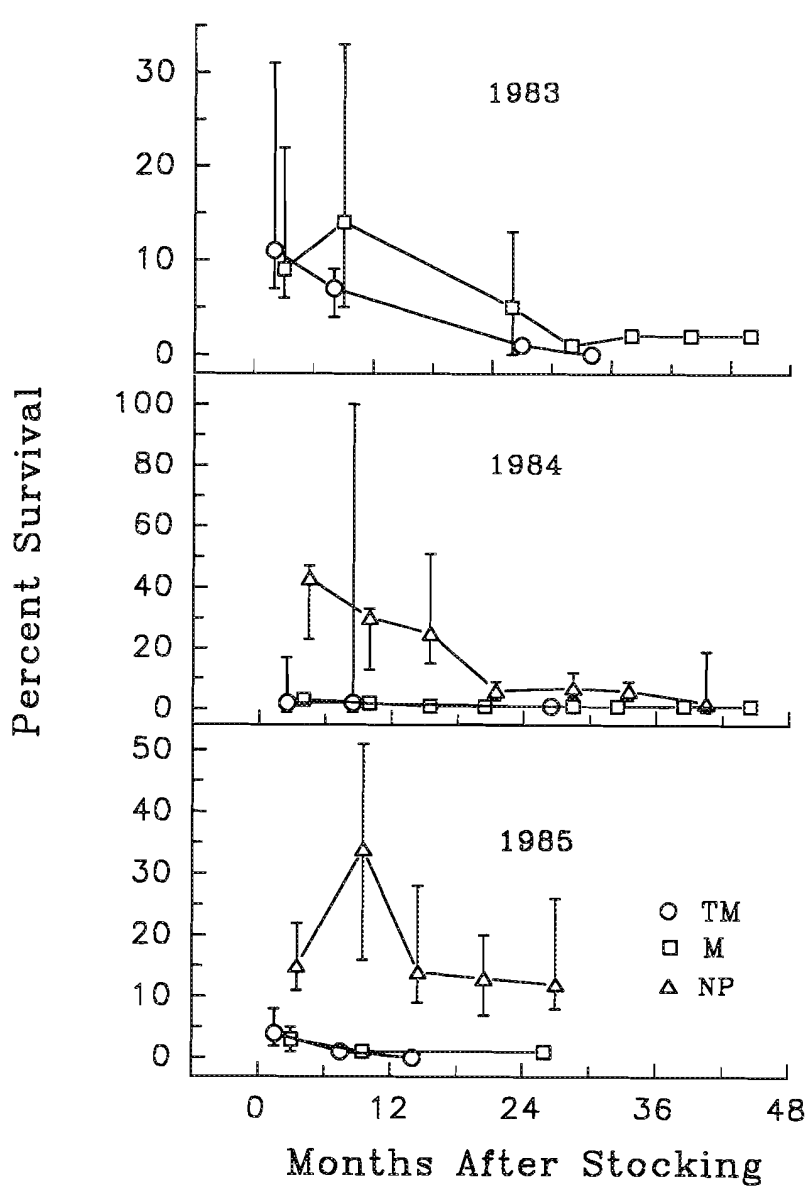

FIG. 2. Survival as a percentage of initial numbers of stocked fish (see Table 1) for tiger muskellunge (TM), muskellunge (M), and northern pike (NP) following introduction into North Reservoir, Ohio, 1983-85. Vertical lines are $95 \%$ confidence intervals and symbols are point estimates based on Schnabel mark-recapture population estimates. Note the different vertical scales among panels.

fits of the data than exponential models based on lack-of-fit tests and residual analysis (Neter et al. 1983). During their first year, relative growth in weight for northern pike and tiger muskellunge exceeded that for muskellunge (ANOVA, $P=0.05$; Tukey's multiple comparisons, $P<0.05$, per Wahl and Stein 1991). In subsequent years, growth differed; muskellunge grew faster than northern pike (Fig. 1; ANCOVA, homogeneity of slope, $P<0.02$ ). Tiger muskellunge grew at an intermediate rate and did not differ from either of its parents (ANCOVA, $P>0.14$ ).

\section{Survival}

Survival through the first fall of juvenile esocids increased with stocking size (Table 2). Fish from the 145-mm length groups stocked in Kokosing and Madison reservoirs survived poorly, preventing application of mark-recapture techniques. In Madison Reservoir, CPUE (number per hour) with electrofishing gear was initially highest for muskellunge $\left(7.4 \cdot h^{-1}\right)$, followed by tiger muskellunge $\left(2.2 \cdot \mathrm{h}^{-1}\right)$ and northern pike $\left(0.2 \cdot \mathrm{h}^{-1}\right)$; similar patterns occurred in Kokosing Reservoir $\left(7.3,3.0\right.$, and $0.9 \cdot \mathrm{h}^{-1}$, respectively). In both reservoirs, CPUE fell dramatically for all taxa during the first $14 \mathrm{~d}$ after stocking; by $30 \mathrm{~d}$ poststocking, survival fell to near zero. In contrast, survival in North Reservoir was substantially higher for 180 - and 205 -mm fish (Table 2). Survival did not differ between 180 - and 205-mm fish, as confidence limits on population estimates overlapped. However, blocking by size, northern pike survived better (15-43\%) than either tiger muskellunge $(2-11 \%)$ or muskellunge $(3-9 \%)$ (Table 2) (ANOVA, $P=0.056$ ).

Northern pike survived better than the other taxa through age 3 or 4 (ANCOVA, homogeneity of intercept and slope, $P<0.03$; except 1985 stocking, homogeneity of slope, $P>0.42$ ); tiger muskellunge and muskellunge survived similarly in all three years (ANCOVA, homogeneity of slope and intercept, $P>0.16$ ). Confidence limits for these estimates provided confirmation; northern pike survived better than muskellunge or tiger muskellunge (Fig. 2). Although muskellunge and tiger muskellunge died at similar rates, muskellunge from both stockings persisted at least 1-2 yr beyond tiger muskellunge (Fig. 2).

\section{Angler Catch}

Esocids were sampled by creel survey and volunteer reports for $5 \mathrm{yr}$ in North Reservoir. Across all years and ages, anglers caught mostly northern pike, followed by muskellunge and tiger muskellunge (Table 3) (chi-square, $P<0.01$ ). Catch rates were highest for northern pike even though they were not stocked in 1983. More northern pike from each stocking were caught as 2 - and 3-yr-old fish than as age $\geq 4$ (chi-square, partitioned degrees of freedom, $P<0.038$ ). Conversely, muskellunge and tiger muskellunge were equally vulnerable across age groups (chi-square, partitioned degrees of freedom, $P>0.12$ ).

\section{Esocid Diets}

Diet analysis by prey number or prey weight yielded similar conclusions (chi-square, $P>0.10$ ). In North Reservoir, the proportion by weight of each prey species consumed was similar among the three taxa and four ages (Table 4). As described by Wahl and Stein (1991), diets of age-0 esocids were dominated 

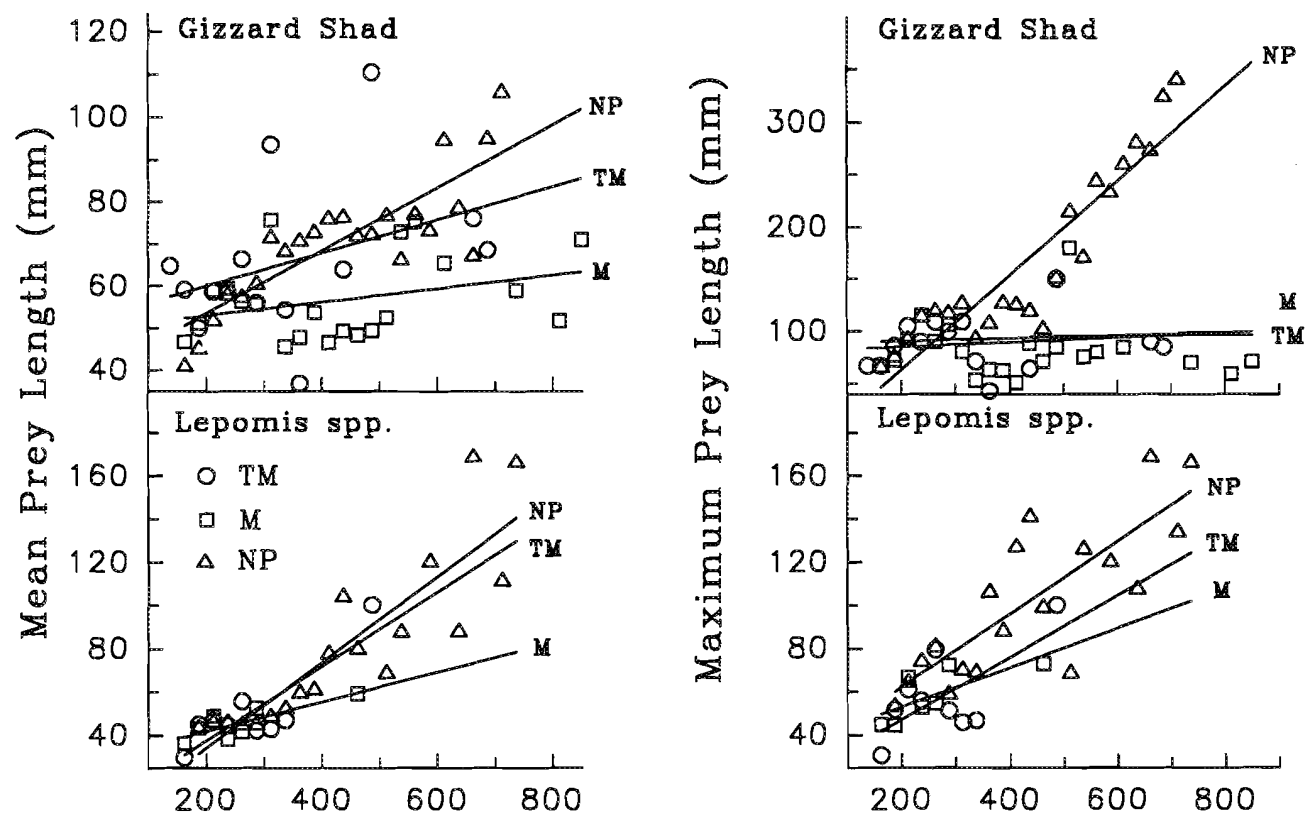

\section{Esocid Length ( $\mathrm{mm}$ )}

FIG. 3. Mean and maximum lengths of gizzard shad and Lepomis spp. consumed by tiger muskellunge (TM), muskellunge (M), and northern pike (NP) in North Reservoir, Ohio, 1983-88. Values indicate lengths of prey eaten by esocids of each $25-\mathrm{mm}$ length interval. Sample sizes can be approximated from Table 4. Lines represent best fits by least squares linear regression.

by gizzard shad (Dorosoma cepedianum) (78-89\%), followed by Lepomis spp. (primarily bluegill (L. macrochirus)), brook silverside (Labidesthes sicculus), Cyprinidae (primarily Notropis spp.), and largemouth bass (Micropterus salmoides) (Table 4). Food habits of age- 1 and older esocids were similar to those for juvenile esocids, dominated by gizzard shad (36-100\%), followed by Lepomis spp. and cyprinids (Table 4). Excluding the few tiger muskellunge sampled as age 3, empty stomachs were common and consistent across all taxa and age groups (Table 4).

In contrast with species composition, size selection varied markedly among esocid age groups. Based on length frequencies, age-0 esocids fed exclusively on young-of-year gizzard shad and Lepomis spp. whereas ages 1-3 fed increasingly on yearling and older prey. In general, mean prey length increased linearly with esocid length for all taxa and prey types. To assess esocid size selectivity, we calculated mean and maximum prey lengths for 25-mm length intervals of each taxon (Fig. 3). Too few cyprinids in the diet prevented comparisons. Within a prey species, regressing mean prey length against predator length for all esocids yielded similar intercepts (ANCOVA, homogeneity of intercept, $P>0.11$ ). However, northern pike selected larger gizzard shad than muskellunge (ANCOVA, homogeneity of slope, $P=0.004$ ). Tiger muskellunge consumed gizzard shad intermediate in size and did not differ from its parents (ANCOVA, $P>0.18$ ). Maximum size of gizzard shad consumed was largest for northern pike (ANCOVA, $P=0.0001$ ). In contrast, no differences among esocid taxa existed in either mean or maximum lengths of Lepomis spp. consumed (ANCOVA, homogeneity of slope, $P>0.07$ ).

Prey size selected also varied with prey species and esocid size. Juvenile northern pike and tiger muskellunge selected smaller mean sizes of Lepomis spp. than gizzard shad (ANCOVA, homogeneity of intercept, $P=0.018$ ). As these two taxa grew, they selected increasingly larger sizes of Lepomis than gizzard shad (ANCOVA, homogeneity of intercept, $P=0.045$ ). Although relationships were not as strong as for the other two taxa, muskellunge exhibited a similar pattern of smaller initial size (ANCOVA, $P=0.06$ ) but more rapid change with predator length (ANCOVA, $P=0.18$ ) of Lepomis as compared with gizzard shad.

\section{Discussion}

\section{Esocid Growth}

Length increased linearly through age 5 for all three esocids. In contrast, two growth stanzas were required to describe weight changes, but weight also increased linearly for age- 1 and older fish. Growth rates in fishes can change after sexual maturity is attained. In esocids, sexual maturity varies with latitude but is generally reached from 2 to $4 \mathrm{yr}$ of age for male and female northern pike and from 3 to $5 \mathrm{yr}$ of age for both sexes of muskellunge (Scott and Crossman 1973). We saw no evidence of changes in growth rates in either length or weight for these ages of fish. However, additional assessments of growth for esocids beyond age- 5 fish are required.

Growth in length was similar among esocids; however, growth in weight varied among both esocid taxa and age groups. Youngof-year northern pike and tiger muskellunge grew faster in weight than muskellunge (Wahl and Stein 1991). In ponds, juvenile muskellunge also grow slower than the other two taxa, but tiger muskellunge outgrows northern pike (Weithman and Anderson 1977). As discussed by Wahl and Stein (1991), small differences in thermal regimes between systems might explain 
these differences in growth among taxa (Bevelhimer et al. 1985). In contrast with young-of-year fish, growth of older esocids was highest for muskellunge, followed by tiger muskellunge and northern pike. Across a variety of waters, muskellunge typically grow faster than northern pike (Carlander 1977). In addition, given that our study reservoirs were near the southern extent of the range of northern pike (Crossman 1978), we expected muskellunge to outgrow northern pike. In contrast, growth similarities between muskellunge and tiger muskellunge were unexpected. From previous work with hybrid vigor in other species (Bevelhimer et al. 1985; Kerby et al. 1987; Johnson et al. 1988; Hooe and Buck 1991), tiger muskellunge would be expected to grow faster than muskellunge. That adult growth does not reflect juvenile growth could derive from several factors: (1) ontogenetic shifts in thermal preferences or foraging abilities in the field or (2) respiration and consumption allometry of juvenile and adult fish (Post 1990). Quantifying respiration, consumption, and excretion across temperatures for all three esocids would be most efficient for evaluating these hypotheses. Although laboratory experiments with large esocids are intractable (see Diana 1982, 1983a), comparing adult growth across thermal regimes would provide insight into our conclusions.

Growth rates could also vary among populations within a taxon. Differences in growth among fish stocks have been observed for other species (Philipp and Whitt 1991), and distinct genetic populations of esocids have been identified (Koppelman and Philipp 1986). The extent to which these genetic differences might influence growth is unclear and future experimental work should quantify effects of temperature and food consumption on growth rates of esocid stocks.

\section{Survival}

Similar to previous work with muskellunge (Hanson et al. 1986; Sern and Andrews 1986) and tiger muskellunge (Carline et al. 1986), survival through fall of all esocids increased with stocking size. Introducing each esocid size in a different study reservoir could have confounded our findings. However, those factors previously identified as critical to survival, such as temperature regimes (Mather and Wahl 1989; Wahl and Stein 1991) and prey and predator communities (Wahl and Stein 1988, 1989), were similar among reservoirs. In our view, large size and reduced fall temperatures combined to increase survival. Specifically, stocking mortality declines with lake temperature (Mather and Wahl 1989) and vulnerability to predation declines for large fingerlings (Stein et al. 1981; Wahl and Stein 1989).

In addition to size effects, survival differs among taxa. Firstyear survival was highest for northern pike. Fewer northern pike were consumed by largemouth bass than were tiger muskellunge, but numbers of northern pike and muskellunge eaten were similar (Wahl and Stein 1989). Stocking mortalities were also similar among taxa (Mather and Wahl 1989). Although predation by resident piscivores and stocking stress account for some losses, other variables such as emigration, disease, and long-term predation also may influence survival of stocked esocids.

Survival through the first fall was useful in predicting longterm survival. For all taxa, most fish died during the first 2 mo after stocking; thereafter, survival remained relatively constant. Overwinter mortality was low, but variable, among years and taxa. Energy reserves dictate overwinter success in some fishes (Hunt 1969; Oliver et al. 1979). Differences in energy reserves among years or taxa may explain some of the variability in overwinter mortality for esocids (Carline et al. 1986). As compared with the high mortality observed during the first year, numbers of fish declined gradually in subsequent years for all taxa. However, northern pike survived better than its congeners through age 4. Although survival was poor for the other taxa, muskellunge persisted for at least $1-2$ yr longer than tiger muskellunge. Data from angled esocids from across North America also suggest that tiger muskellunge longevity is lower than for muskellunge (Casselman and Crossman 1986).

\section{Angler Catch}

In ponds, northern pike are more vulnerable to angling than tiger muskellunge or muskellunge (Beyerle 1973; Weithman and Anderson 1976). Greater catchability combined with higher survival yielded more creeled northern pike as compared with its congeners in our reservoirs. Northem pike were caught at smaller sizes and younger ages than other taxa. In spite of its higher vulnerability to angling however, fewer tiger muskellunge were caught than muskellunge, owing to greater survival in muskellunge. In general, tiger muskellunge did not survive sufficiently long to reach harvestable size.

\section{Esocid Diets}

Esocids of all ages were almost exclusively piscivorous. Like juvenile esocids (Mauck and Coble 1971; Weithman and Anderson 1977; Wahl and Stein 1988), larger esocids fed predominantly on gizzard shad. Centrarchids and cyprinids followed gizzard shad in importance in diets. Because gizzard shad are more easily captured than centrarchids owing to their lack of spines and antipredatory behavior (Reist 1980; Moody et al. 1983; Webb 1986; Wahl and Stein 1988), gizzard shad are selected by esocids.

As documented for other fish predators (Knight et al. 1984; Johnson et al. 1988), esocids consume larger prey as they grow. Even so, prey size preference varied among taxa; northern pike chose the largest mean and maximum sizes of gizzard shad. Whether these differences relate to morphological or behavioral differences among taxa is unclear. Preliminary comparisons of jaw morphology suggest that northern pike have wider mouths than the other two taxa for young-of-year fish (D.H. Wahl, unpublished); similar data for adult fish are not available. However, other morphometric variables associated with the head of adults are relatively larger for northern pike than for muskellunge; tiger muskellunge are intermediate (Casselman et al. 1986). Behavioral differences among predators (i.e., habitat selection, Wahl and Stein 1989) also might influence prey selection by affecting encounter rates and consumption of various sizes of prey.

Prey species and esocid size affected prey size selection. Large individuals of all three taxa selected larger sizes of centrarchids than gizzard shad; prey lengths increased more rapidly with esocid length for centrarchids than for gizzard shad. In contrast, small esocids selected smaller mean sizes of centrarchids than gizzard shad, as predicted from previous laboratory and field experiments quantifying optimal sizes (Gillen et al. 1981; Carline et al. 1986; Wahl and Stein 1988). These differences between esocid size groups may be related to changes in optimal prey sizes for larger esocids or to changes in prey availability. Because gizzard shad often experience high overwinter mortality (Jenkins and Morais 1978; Adams et al. 1982; Storck 1986), their populations are dominated by young-of-year. Hence, adult esocids may have been constrained to small sizes when feeding on gizzard shad. 


\section{Management Implications}

In our work, most esocid mortality had occurred by the first fall; survival of all three esocids was relatively constant thereafter. As a result, survival through fall can be reliably used as an index of recruitment for both stocked and natural esocid populations.

All three esocids survived better when stocked at sizes $>175 \mathrm{~mm}$. These findings reinforce previous work that suggests that esocids should be stocked at large sizes $(200-250 \mathrm{~mm})$ in the fall to minimize predation mortality (Stein et al. 1981; Wahl and Stein 1989) and reduce losses to thermal stress (Mather et al. 1986; Mather and Wahl 1989). However, final selection of a stocking size depends on complex relationships between hatchery costs and characteristics of individual lakes, such as predator and prey abundance and size distributions and thermal regimes. Development of a bioeconomic model incorporating these variables would allow managers to create cost-efficient, system-specific stocking programs.

Taxon choice for an individual lake or reservoir depends on growth, survival, harvest, angler preferences, and management objectives. These decisions also should consider the natural distributions of esocids (Crossman 1978), effects on native populations (Inskip and Magnuson 1986), and conservation of genetic stocks (Koppelman and Philipp 1986). If the management objective is to maximize either the number of fish in a lake or angler catch, then northern pike should be chosen, owing to its high survival and angler catch. For trophy fisheries, muskellunge should be selected, for it grows faster than northern pike and survival and catch rates exceed those for tiger muskellunge. Tiger muskellunge are only appropriate when hatchery costs must be minimized or when subsequent reproduction is a concern.

\section{Acknowledgments}

Many individuals associated with the Aquatic Ecology Laboratory at The Ohio State University provided volunteer and technical assistance; in particular, help with field sampling by $\mathrm{K}$. Bruner, D. Imhoff, C. Habicht, L. Einfalt, J. Bohne, P. Cunningham, J. Hageman, P. Winkle, D. Welty, P. Crane, and J. Dettmers were critical to this study. P. Hillman and J. Droder assisted with the creel surveys. Statistical support was provided by the Statistical Consulting Service, The Ohio State University. T. Nagel (London State Fish Hatchery) and P. Keys (Hebron State Fish Hatchery) provided esocids, and D.B. Apgear coordinated activities with the Ohio Division of Wildlife. T. Szendrey and the Aquatic Ecology Discussion Group at the Kaskaskia Biological Station, Illinois Natural History Survey, provided helpful comments on the manuscript. This study was supported in part by funds from the Federal Aid in Fish Restoration Act under project F-57-R administered by the Ohio Division of Wildlife.

\section{References}

AdAmS, S.M., R.B. MCLean, AND M.M. HuffMan. 1982. Structuring of a predator population through temperature-mediated effects on prey availability. Can. J. Fish. Aquat. Sci. 38: 387-393.

BEVELHIMER, M.S., R.A. STEIN, AND R.F. CARI INE. 1985. Assessing significance of physiological differences among three esocids with a bioenergetics model. Can. J. Fish. Aquat. Sci. 42: 57-69.

BEYERLE, G.B. 1973. Comparative growth, survival and vulnerability to angling of northern pike, muskellunge, and hybrid tiger muskellunge in a small lake. Mich. Dep. Nat. Resour. Fish. Res. Rep. No. 179: 11 p.

BIMBER, D.L. 1982. Longevity, growth and mortality of muskellunge in Chautauqua Lake, New York. N.Y. Fish Game J. 29: 134-141.

CARLANDER, K.D. 1977. Handbook of freshwater fishery biology. Vol. 2. Iowa State University Press, Ames. Iowa.

CARL.INE, R.F., R.A. STEIN, AND L.M. RILEY. 1986. Effects of size at stocking, season, largemouth bass predation, and forage abundance on survival of tiger muskellunge. Am. Fish. Soc. Spec. Publ. 15: 151-167.

CASSELMAN, J.M. 1978. Effects of environmental factors on growth, survival, activity, and exploitation of northern pike. Am. Fish. Soc. Spec. Publ. 11: $114-128$.

CASSelman, J.M., AND E.J. Crossman. 1986. Size, age, and growth of trophy muskellunge and muskellunge - northern pike hybrids - the cleithrum project, 1979-1983. Am. Fish. Soc. Spec. Publ. 15: 93-110.

Casselman, J.M., E.J. Crossman, P.E. Ihssen, J.D. Reist, and H.E. Booke. 1986. Identification of muskellunge, northern pike, and their hybrids. Am. Fish. Soc. Spec. Publ. 15: 1446.

CROSSMAN, E.J. 1965. Hybridization in the family Esocidae. J. Fish. Res. Board Can. 22: 1261-1292.

CRosSmAn, E.J. 1978. Taxonomy and distribution of North American esocids. Am. Fish. Soc. Spec. Publ. 11: 13-26.

DIANA, J.S. 1982. An experimental analysis of the metabolic rate and food utilization of northern pike. Comp. Biochem. Physiol. 71 A: 395-399.

DiANA, J.S. 1983a. An energy budget for northern pike (Esox lucius). Can. J. Zool. 61: 1968-1975.

DIANA, J.S. 1983b. Growth, maturation and production of northern pike in three Michigan Lakes. Trans. Am. Fish. Soc. 112: 38-46.

FOSTER, J.R. 1977. Pulsed gastric lavage: an efficient method of removing the stomach contents of live fish. Prog. Fish-Cult. 39: 166-169.

Frost, W.E. 1954. The food of pike (Esox lucius L.) in Windermere. J. Anim. Ecol. 23: 339-360.

Gillen, A.L., R.A. STEIN, AND R.F. CARLINE. 1981. Predation by pellet-reared tiger muskellunge on minnows and bluegills in experimental systems. Trans. Am. Fish. Soc. 110: 197-209.

Hanson, D.A., M.D. Staggs, S.L. Serns, L.D. Johnson, AND L.M. ANDREws. 1986. Survival of stocked muskellunge eggs, fry, and fingerlings in Wisconsin lakes. Am. Fish. Soc. Spec. Publ. 15: 216-228.

HESSER, R.B. 1978. Management implication of hybrid esocids in Pennsylvania. Am. Fish. Soc. Spec. Publ. 11: 302-307.

HoOE, M.L., AND D.H. Buck. 1991. Evaluation of $F_{1}$ hybrid crappies as sport fish in small impoundments. N. Am. J. Fish. Manage. 11: 564-571.

HUNT, R.L. 1969. Overwinter survival of wild fingerling brook trout in Lawrence Creek, Wisconsin. J. Fish. Res. Board Can. 26: 1473-1483.

INSKIP, P.D. 1986. Negative associations between abundances of muskellunge and northern pike: evidence and possible explanations. Am. Fish. Soc. Spec. Publ. 15: 135-150.

INSKIP, P.D., AND J.J. MAGNUSON, 1986. Fluctuations in growth rate and condition of muskellunge and northern pike in Escanaba Lake, Wisconsin. Am. Fish. Soc. Spec. Publ. 15: 176-188.

JENKINS, R.M., AND D.I. MORAIS. 1978. Prey-predator relations in the predator-stocking-evaluation reservoirs. Proc. Annu. Conf. Southeast. Assoc. Fish WildI. Agencies 30: 141-157.

JOHNSON, B.L., D.L. SMITH, AND R.F. CARLINE. 1988. Habitat preferences, survival, growth, foods, and harvest of walleyes and walleye $\times$ sauger hybrids. N. Am. J. Fish. Manage. 8: 292-304.

KERBY, J.H., J.M. HINSHAw, AND M.T. HUISH. 1987. Increased growth and production of striped bass $\times$ white bass hybrids in earthen ponds. J. World Aquacult. Soc. 18: $35-43$.

KIPLING, L. 1983. Changes in the growth of pike (Esox lucius). J. Anim. Ecol. 52: 647-657.

KNIGHT, R.L., F.J. MARGRAF, AND R.F. CARLINE. 1984. Piscivory by walleyes and yellow perch in western Lake Erie. Trans. Am. Fish. Soc. 113: $677-693$

Koppelman, J.B., AND D.P. PHILIPP. 1986. Genetic applications in muskellunge management. Am. Fish. Soc. Spec. Publ. 15: 111-121.

LAWLER, G.H. 1965. The food of the pike (Esox lucius) in Heming Lake, Manitoba. J. Fish. Res. Board Can. 22: 1357-1377.

MANN, R.H. 1976. Observations on the age, growth, reproduction and food of the pike Esox lucius $(L)$ in two rivers in southern England. J. Fish. Biol. 8: 179-197.

MATHER, M.E., R.A. STEIN, AND R.F. CARIINE. 1986. Environmental assessment of mortality and hyperglycemia in tiger muskellunge due to stocking stressors. Trans. Am. Fish. Soc. 115: 762-770.

MATHER, M.E., AND D.H. WAHL. 1989. Comparative mortality of three esocids due to stocking stressors. Can. J. Fish. Aquat. Sci. 46: 214-217.

MAUCK, W.L., AND D.W. COBLE. 1971. Vulnerability of some fishes to northern pike (Esox lucius) predation. J. Fish. Res. Board Can. 28: 957-969.

MoODY, R.C., J.M. HELLAND, AND R.A. STEIN. 1983. Escape tactics used by bluegills and fathead minnows to avoid predation by tiger muskellunge. Environ. Biol. Fishes 8: 61-65.

NETER, J., W. WASSERMAN, AND M.H. KUTNER. 1983. Applied linear regression models. Richard D. Irwin, Incorporated. Homewood, Ill. 
NEWMAN, D.L., AND T.W. SToRCK. 1986. Angler catch, growth, and hooking mortality of tiger muskellunge in small centrarchid-dominated impoundments. Am. Fish. Soc. Spec. Publ. 15: 346-351.

Oliver, J.D., G.F. Holeton, AND K.E. CHUA. 1979. Overwinter mortality of fingerling smallmouth bass in relation to size, relative energy stores, and environmental temperature. Trans. Am. Fish. Soc. 108: 130-136.

Philipe, D.P., AND G.S. WHIT. 1991. Survival and growth of northern, Florida, and reciprocal $\mathrm{F}_{1}$ hybrid largemouth bass in central Illinois. Trans. Am. Fish. Soc. 120: 58-64.

POST, J.R. 1990. Metabolic allometry of larval and juvenile yellow perch (Perca flavescens): in situ estimates and bioenergeric models. Can. J. Fish. Aquat. Sci. 47: 554-560.

REIST, J.D. 1980. Selective predation upon pelvic phenotypes of brook stickleback (Culaea inconstarls) by northern pike (Esox lucius). Can. J. Zool. 58: $1245-1252$.

RICKER, W.E. 1975. Computation and interpretation of biological statistics of fish populations. Bull. Fish. Res. Board Can. 191: 382 p.

Scott, W.B., And E.J. Crossman. 1973. Freshwater fishes of Canada. Bull. Fish. Res. Board Can. 184.

SERNS, S.L., AND L.M. ANDREws. 1986. Comparative survival and growth of three sizes of muskellunge fingerlings stocked in four northern Wisconsin lakes. Am. Fish. Soc. Spec. Publ. 15: 229-237.

STEIN, R.A., R.F. CARLINE, AND R.S. HAYWARD. 1981. Largemouth bass predation on stocked tiger muskellunge. Trans. Am. Fish. Soc. 110: 604-612.
STORCK, T.W. 1986. Importance of gizzard shad in the diet of largemouth bass in Lake Shelbyville, Illinois. Trans. Am. Fish. Soc. 115: 21-27.

TOMCKO, C.M., R.A. STEIN, AND R.F. CARLINE. 1984. Predation by tiger muskellunge on bluegill: effects of predator experience, vegetation, and prey density. Trans. Am. Fish. Soc. 113: 588-594.

WAHL, D.H., AND R.A. STEIN. 1988. Selective predation by three esocids: the role of prey behavior and morphology. Trans. Am. Fish. Soc. 117: 142-151.

WAHL, D.H., AND R.A. STEIN. 1989. Comparative vulnerability of three esocids to largemouth bass (Micropteris salmoides) predation. Can. J. Fish. Aquat. Sci. 46: 2095-2103.

WAHL, D.H., AND R.A. STEIN. 1991. Food consumption and growth of three esocids: field tests of a bioenergetic model. Trans. Am. Fish. Soc. 120: 230-246.

WeBB, P.W.1986. Effect of body form and response threshold on the vulnerability of four species of teleost prey attacked by largemouth bass (Micropterus salmoides). Can. J. Fish. Aquat. Sci. 43: 763-771.

WeITHMAn, A.S., AND R.O. ANDERSON. 1976. Angling vulnerability of Esocidae. Proc. Annu. Conf. Southeast. Assoc. Fish Wildl. Agencies 30: 99-102.

Weithman, A.S., AND R.O. ANDERSON. 1977. Survival, growth, and prey of Esocidae in experimental systems. Trans. Am. Fish. Soc. 106: 424-430.

Wingate, P.J. 1986. Philosophy of muskellunge management. Am. Fish. Soc. Spec. Publ. 15: 199-202.

WOLFERT, D.R., AND T.J. Mil. in eastern Lake Ontario. Trans. Am. Fish. Soc. 107: 696-702. 